\title{
Can Psychological Questionnaires Predict the Academic Talent during Higher Education Studies?
}

\author{
János Szabó \\ Doctoral candidate, University of Pécs, Institute of Psychology \\ E-mail: szabo.janos@pte.hu;
}

Balázs Fábián

PhD student; Doctoral School of Health Sciences

Institute of Behavioural Sciences

University of Debrecen-

Received: May 12, 2020

Accepted: June 16, 2020

Published: August 1, 2020

doi:10.5296/jse.v10i3.17018

URL: https://doi.org/10.5296/jse.v10i3.17018

\begin{abstract}
The space between secondary-school gifted education and starting one's academic career is what is termed higher education talent management in this context. The "talent management", in the aspect of the Hungarian higher education, refers to academically talented students, who prepare to the scientific career. So, the talent management in higher education can be imagined as a bridge between formal school studies and scientific career. In this research, I investigated empirically, with psychological questionnaires and other indicators what features and personality-traits contribute to academic/scientific success (number of scientific activities). 144 talented students were recruited to this research; all of them participated in a talent program or conception. The 5-page test pack included mainly professional psychological tests. The data was analyzed with linear regression statistical method, where the dependent variable was an index calculated from the students' scientific activities. The regression model has been significant $(\mathrm{F}=3,453 ; \mathrm{df}=128 ; \mathrm{p}<0,05)$, but owing to the weak R-square value $(0,226)$, the results are not suitable to the practical adaptation and talent identification.
\end{abstract}

Keywords: talent management, honor-students, gifted students, academic talent, higher education 


\section{Introduction}

Comparing with the gifted education during primary and secondary studies, the higher-education talent management is an under-investigated area. A lot of study approaches this topic from HR-aspect (Neri, \& Wilkins, 2019; Gandy, Harrison \& Gold, 2018; Boichenko, 2015). Among the studies written about talented students, just a few investigate the talented students with empirical methods (Cognard-Black \& Spisak, 2019). The majority of these was conducted in the U.S.A, where 300,000 - 400,000 students participate in honor programs (Cognard-Black \& Spisak, 2019). These honor programs means the talent management during higher-education studies. Although, the conceptions of these programs are different in institutes, universities; there are some common features. For example: the "talented" refers to the academically talented undergraduate students (Cognard-Black \& Spisak, 2019). So, when we read the literature of higher-education talent management, we meet mainly with "honor student" term, instead of talented student. Hence, the honor program is an American conception, it would be not appropriate to use at the case of Hungarian conceptions.

In the aspect of talent-management programs, the European universities are underrepresented, compared to American ones. Much less university has talent program in Europe, and the majority of these are found in the Netherlands (Wolfensberger, 2015). Hence, empirical researches about talented students in higher education are very rare in Europe. The few examples are mainly originated also from the Netherlands (Scager et al 2012; Hammer, 2015). So, conducting an empirical research, involving talented university students, is a fairly new approach.

The purpose of this study is not comparing the Hungarian higher education talent management to ones of another nations. Although, it is essential to clarify what "talent" means in this context. The Hungarian talent management conceptions - how it is elaborated below - are based on the scientific reinforcement (fostering a new generation of scientists). So, they are focusing rather on the scientific activities (e.g. conducting own researches, publishing into scientific journals) and scientific career, than on professional career and labour market. So, the students, who were investigated on this study, were "scientifically" talented. It means that, in the Hungarian higher education talent management, a "talented" student means a potential scientist/university teacher/faculty member. That is why, the main criteria during $\mathrm{PhD}$ applying process is a student's earlier research activities (what he/she performed during his/her higher education studies).

There are studies that explore scientists' personalities and cognition. Examples of these studies address the unique personality and individual traits of scientists (Simonton, 2004a; Feist, 2006; Helmreich, Spence, Beane, Lucker \& Matthews, 1980). The psychology of science, a sub-area of psychology, deals with the mental background of the motivational, cognitive, and creative factors at scientific activities (Feist, 2006). This space between secondary-school gifted education and starting one's academic career is what is termed higher education talent management, in Hungary. So, the talent management in higher education can be imagined as a bridge between formal school studies and scientific career. Many scientists 
have already been involved in scientific research during their university studies (Feist, 2006). However, in Hungary, only few higher education institutes have professional and formal talent management system. Fortunately, some programs and projects have been founded which try to connect the two areas (higher-, and secondary education). These programs filter out gifted students in the secondary schools, and then help them get involved in an appropriate gifted education form or format (Balogh, 2012). This is why this topic is an interesting one and a new potential area to investigate. So, investigating this topic means filling the gap between the literature of psychology of science, and giftedness at the primary and secondary schools, because it is not sure that the students with best high school GPA will be the most successful scientists.

Another argument of higher-education talent development must be mentioned. Higher education has become a standardized, structured approach of mass education in many countries over the past few decades. This is a shift from what the university was for centuries; a form of gifted education in and of itself (Balogh, 2012). Therefore, we must identify talented students in this mass-education approach and provide them appropriate services. We must pay critical attention to prevent gifted secondary school students from dropping out of their studies, and at the same time, locate new potential scientists among the university students.

There are studies which used psychological questionnaires or scales to measure talented students in higher education. These studies usually found differences between talented and non-talented students. For example: Talented students are more opened to the experiences and more conscientious than their non talented peers (Long \& Lange, 2002). An investigation used BIG5 questionnaire which proved that talented students are more conscientious, open, emotionally instable, and introverted (Achtenberg, 2005; Cross, 2018). Besides psychological features, the GPA, learning strategy (Cuevas, Schreiner, Kim, \& Bloom, 2017), and behavioral features are also used methods at investigation of this topic. The GPA is higher at honor students than non honor mates (Cognard-Black \& Spisak, 2019), but this does not prove to be true in every case (Shushok, 2006). The most investigated features connect to the living on the campus, free-time, connect with the faculty and faculty member, and participating in activities. The honor students train and sleep more, than their non-honor mates; they consult more with their teachers; they participate more in religious activities, in charity work, and community service (Cognard-Black \& Spisak, 2019).

In this research, I tried to investigate empirically, with psychological questionnaires and other indicators what features, personality-traits contribute to academic/scientific success (number of scientific activities). Of course, it cannot be assumed that the academic talent originates only from personality, I just wanted to test whether there exist such Hungarian psychological scales that can predict the scientific performances among talented students. This would be helpful at applying process of talent management programs (even honor programs) or even at $\mathrm{PhD}$-applying process.

According to an earlier research, that investigated such university teachers, professors who supervise gifted students (help them preparing to the scientific career), it has been emerged 
that the faculty members think similarly about talented students. Analyzing the opinions of university teachers, it has been found that there are six attributes what emerge from the used 66 attributes: (1) Recognizing the coherency; (2) Highlighting the meaning; (3) Curiosity; (4) Self-dependence; (5) Endurance, engagement; (6) Logical thinking. These six attributes were not only emerging, but also common among different science domains (e.g. humanities, economic, medicine) (Szabó, 2018).

So, during this research, I tested with psychometrical methods (personality trait questionnaires, Advanced Raven Test, etc.) whether the used psychometrical measurements of these six attributes can predict the scientific performance or attitude toward scientific career of talented students (potential scientists)

\section{The importance of talent management in early adulthood: Why gifted programs should continue past secondary education.}

As mentioned above, academic talent in this developmental period of young adulthood is less investigated compared to other periods (scientific career in adulthood, formal school study period). This timeframe is different from others, not only in developmental aspect, but also in educational and professional aspect.

At this age period, talent management is less about diagnostics and more about the evaluation of already earned competencies. One of the main goals of talent management in adulthood is preventing talents and skills from atrophy. This time period is also an opportunity to synthesize existing skills and develop new talents. Current diagnostic tools only address a narrow layer or a minority of talented children and emerging adults (Gyarmathy, 2010). Therefore, "higher-education talent management" is a new domain or opportunity to identify new emerging talents.

Higher-education talent management is an option or alternative to find new talents because it evaluates students in such sciences that might not be taught in primary or secondary school (e.g., medicine, law, psychology, economics, sociology, environmental science). Students rarely encounter with these subjects during secondary school studies. Other novelty of the higher education studies: students can choose from many applied sciences and this gives opportunity for more youngsters to demonstrate and investigate their talents. For example, a student, who was not identified as outstanding in biology, may now have the opportunity to conduct relevant important research work in the related fields of medicine, psychology, agrarian sciences, or bio-engineering.

The sooner talent is recognized, the easier it is to nurture and foster it. The college years comprise a seminal developmental period with important changes (Allen \& Land, 1999; Damon, Lerner, Kuhn, Siegler \& Eisenberg, 2008; Lerner \& Lerner, 1999; Siegel, 1999). Development at this age creates continued life-course trajectories. These trajectories include professional and personal identity (Rodgers \& Scott, 2008) that is influenced by personality (Damon et al, 2008), meaningful connections (Allen \& Land, 1999; Siegel 1999), and identity (Hébert \& McBee, 2007). College is often a time of identity search where executive functioning and abstract thinking matures, and the real and matured self-identity 
manifests in searching questions of "Who am I?" in context and as a stable identity (Levinson, Darrow, Klein, Levinson, \& McKee, 1978). Many students recognize their interests and what they want to do as a vocation (Shapin, 2009). In scientific psychology, this period is referred to as "the time of crystallization" due to one's engagement and goodness-of-fit in their scientific career and identity (Feist, 2011).

In an optimal case, the individual differentiates from their parents (family of origin), they leave the family home and are removed from their parents' oversight. In this time, they begin to obtain freedom to explore interests, and with this freedom, opportunity arises to prove their worth and value. The more opportunities that are provided to young people during this time, the better they can develop their own critical thinking and choose a self-congruent career (Lubinski \& Humphreys, 1992).

Another argument for higher-education talent development is the fact that individual differences decrease as people age. In primary school age children, test scores and grades somewhat correlate with IQ level $(0.4-0.7)$, but this tendency cannot be observed among the population in colleges and universities. The reason for this is that education becomes more selective - like a funnel - and the initial differences among mental capacities decrease like a mathematical ceiling effect (Mackintosh, 1998).

\section{Scientific creativity and the attributes of scientists}

The main goal of Hungarian talent development is encouraging the life of the mind, involving the young professional in the academic guild, and fostering the next generation of scientists and academics. University professors strive to develop scientific creativity in diverse ways. But what exactly is scientific creativity? And what factors or variables comprise it? In this section, we will survey what this notion means and which factors were found to be important and relevant in earlier research studies.

Scientific creativity means the totality of thoughts and behaviors necessary to advance discipline-specific knowledge. As science progresses there needs to be validation from the professional society and through the rigorous process of academic research (theoretical substantiating, hypothesis construction, researching, publication, lecture) (Feist, 2006). This aspect of creativity manifests in the connection of the person, relationships, and their diverse environments. Namely, the researcher investigates and tests and hypothesizes phenomena and relationships of the world. The base of scientific creativity is in many instances an intuitive thought, a supposition, or a moment of coincidence found in unexpected nexuses. It is necessary to mention that this kind of creativity nowadays has become a teamwork approach rather than an individual activity (Feist, 2006).

Feist (2006) has described this construct of scientific creativity, and he has also collected and organized the correlating attributes of the productive scientific career:

- Cognitive traits: open-mindedness, patience, flexibility, psychological mindedness

- Motivation traits: ambition, drive, intrinsic motivation

- Social traits: dominance, arrogance, hostility, introversion, self-confidence. 
A scientific career is, partially, measured by performance. This performance revolves around contribution to the scientific community, often through publications. The number of published works correlates with hard work, with competence, with one's professional background, and with a sense of competition. However, if we look at the citation rate, then only hard work and professional background correlate with this rate (Simonton, 2004b).

Finally, we must speak about the measurement of the scientific creativity. This issue can be approached even from four aspects: from the aspect of the scientific product (the article), from the aspect of the scientists' personalities, from the aspects of creative process, and finally from the aspect of the situation (Stumpf, 1995). The product can be measured on the one hand by the SCI (Science Citation Index - How many times was the article cited). The other way is rating by experts. This measures the quality by similar viewpoints, like novelty, resolution (utility at the problems in the realty), etc. This way is used at the evaluating of the OTDK works. The creative process means those mental steps and activities which are necessary to carry out a research. For example: extended effort, verification, elaboration, etc. These processes can be inspected by introspective reports and they are very variable: which these steps are, which the order of these steps is, they vary at every research and every science area. The creative situation is the summary of those factors which contribute to the scientific creativity. A lot of factors are included into this: the spirit of the times, politicalcultural- historical- ideological background, the needs of the society, etc. And finally, from the aspect of the researchers' personalities what is described in the earlier chapters. This part contains the personality traits and cognitive factors which were mentioned above (Stumpf, 1995). And this is the way how I have investigated the talent-factors in this study.

\section{Higher-education talent development forms in Hungary}

This study has been conducted in the frame of the Hungarian talent development system where we refer to "talented students" as persons who take part in additional opportunities besides the obligatory studies (by joining a szakkollégium or a research group or a talent program; managing their own research project; writing a TDK-work). The "talent management" programs in Hungarian higher education refers to the system in a university which helps students become involved in scientific research, to present their results in scientific conferences, or to publish their papers in peer-reviewed journals. The main role in higher education talent management belongs to the supervising university professors who teach the talented, interested students how to conduct scientific research and participate in the professional guild. There are also administrators who help the talented students to find scholarships, conferences, and research supplement funding and opportunities. In Hungary, there is a statute in the constitution (2005. CXXXIX. statute 66. §), according to this regulation, every higher education institute (all colleges and universities) has to take care about its talented students in a talent-management form (Bodnár, Takács, Balogh, 2011).

Wolfensberger (2015) introduces 11 countries detailed: with describing the higher-education institutes, the education system, the educational forms and these are supplemented with empirical data. Similarly to the introduced countries, there are also some universities in Hungary, where complex honor-education forms are used which worth to mention. The other 
reason of introducing the Hungarian forms is that: I have collected the data here.

In Hungary, there are more conceptions which are available for the talented students who are interested in the scientific career. A lot of colleges and universities have own local conceptions, for example: research-seminars, lecture-series, vocational trainings, workshops, learning-groups, even summer-camps which are important parts of the university-life. The majority of them involve just few students in favor of the effective work/learning. The base of these conceptions is mainly the initiation of a teacher or the enthusiasm of students. In these forms, the informal, collegial, or even friendly relation is very important in favor of the effective cooperation among the students and the teachers. They mainly work just inside the walls of a department/an institute, they are less structural and more informal, so it is harder to investigate them empirically, than the standard national talent developmental conceptions (OTDK, Champaign of Szakkollégiums, global-university talent programs) which works similarly around the universities of Hungary. But they are important part of the scientific talent management, because in the frame of these groups (seminars, workshops, etc.), the students can learn easier the bases of the scientific research's methods, owing to the little-group-modality, the low headcount, the informal relations. Hence, the higher-education became mass-education, these forms have been crowded out from official study-plan (Hrubos, 1999).

Besides of these local low-headcounter-forms, there are more central/national conceptions (expended into the level of whole nation/university) which help for the students to start and to continue their scientific career. There are projects which overarch to secondary schools (for example: Talent-passport Program, Szinapszis mentor-program, Talent-bridges Program), as a bridge between gifted education and higher education. The goal of these programs is to reach the inquiring secondary school students: They continue supplementing the talent-management process and help the students to fit in the new university-atmosphere. These conceptions mainly work in the frames of mentor-tutor system.

One of the main talent management forms is the TDK-system. "TDK" and "OTDK" terms mean Scientific Conference for Students and National Scientific Conference for Students. The OTDK (national version) is organized in every second year. It is a national research competition among the most talented university students in Hungary. TDK (local version) is organized every half year. The university-students can qualify to the OTDK by their TDK-results. There are 13 sections according to 13 science domains (e.g.: social-sciences, chemistry, medicine, biology, humanities, law, etc.). Every section is split into c.a. 10-30 sub-sections which are based on a narrow field or a special topic (e.g.: personality psychology, developmental psychology, educational psychology, criminal psychology, etc.). At the end of the conference, the best researches (and the students who conducted them) are awarded with first/second/third place, or special prize. The participation and the award in OTDK act positively at the $\mathrm{PhD}$ applying process.

The other main talent management form is the Movement of Szakkollégium. This is a group-based talent management conception. The szakkollégiums work in the frame of a university (like guilds). The organizational structure of szakkollégiums bases on democracy, 


\section{Al Macrothink}

the members continuously form that. That is the reason, why the rules, programs, number of members, focus of development, and requirements of szakkollégiums in different universities can be very diverse. Just the three pillars are common: living together; forming a community; endeavor toward mastery. This conception is similar to "community of practice" form in the U.S.A. (Hua, Shore, \& Makarova, 2012). The accredited szakkollégiums form into a network that is supervised by the committee of Movement of szakkollégium. The delegates of szakkollégiums ordinary meet to debate about the issues pertained to the movement of szakkollégium. Any szakkollégium from any university can join to this network (and become accredited szakkollégium), if it succeed the requirements that are based on the above mentioned three pillar.

Beside the two national talent management form (OTDK; Szakkollégium), there are complex higher-education talent developmental programs in the universities. These mean excellent opportunity for students who want to join to the scientific work, to supplement their studies, and to get better in their profession/science-area. In these forms, earlier unknown competences of the students may appear during the talent supplement process: strong and stable vocational identity; motivation for the research-work; but interest about earlier-far-believed science areas also can be formed. Some of them are similar to honor programs.

\section{Sample}

The 5-page-test-pack was filled out by 144 talented students $(\mathrm{N}=144)$. This number is appropriate: according to a power analysis by $\mathrm{G}^{*}$ Power program (with 0.05 significance level; with 0.5 effect size; with 0.8 power), it is offered at least 128 person. All of the students participated in some form of talent-development in higher education: either they wrote TDK-work (this was the base of recruitment in University of Pécs, Eszterházy Károly University, University of Miskolc) or they participated in DETEP-program (this is a unique talent-development form in University of Debrecen; the base of recruitment in University of Debrecen).

The mean of age among the participants was 22,84 years; the youngest was 19 , the oldest was 32 years old. The sample is comparatively balanced in the aspect of gender: 79 women $(54,9 \%)$ and 65 men $(45,1 \%)$ filled out the test-pack. Circa half of the participants $(52,8 \%$ 76 students) finished his/her high school studies in a 4-years gymnasium. 31 students $(21,5 \%)$ attend 6 or 8 years gymnasium. 37 students $(25,7 \%)$ graduated in a vocational high school. The students came from every science-domain, what is represented on Figure 1. 


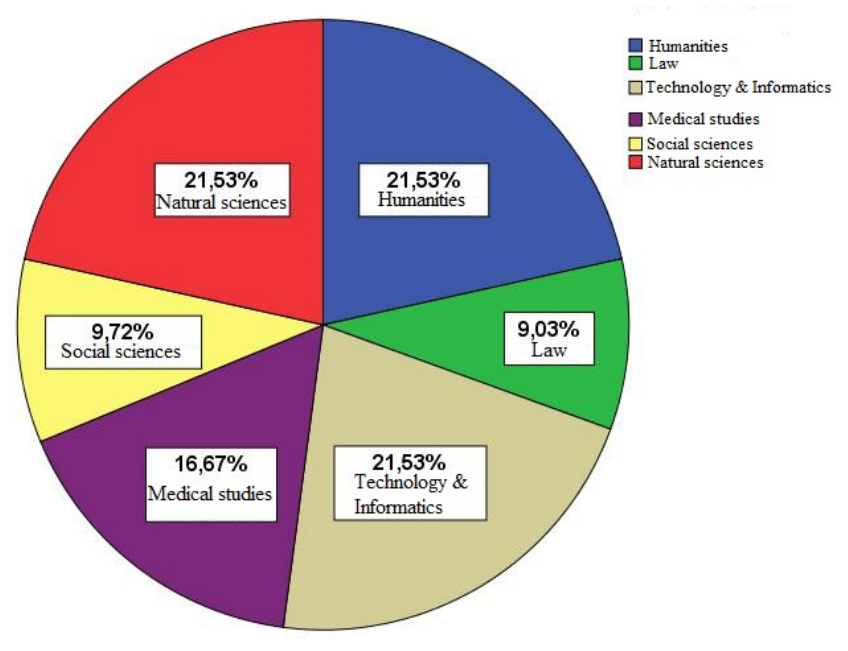

Figure 1. Distribution of science domains

\section{Method}

I used questionnaire-method. The test-pack contained personality-trait questionnaires or subscales, APM-Test, demographic questions, questions about high-school studies, questions about career-plans, and an attribute-choosing task. The construction of this test-pack is summarized by Table 2. I got research-ethical permission from the United Ethical Review Committee for Research in Psychology (Number: 2018-46).

The participation was voluntary and anonym, but there was a confirmation pronouncement about privacy policy on the first page. The students could decide "agree" or "disagree" with the participation. Everybody chose "agree" option. The first pack of the questions was about the demographical background (gender, age, residence, major, etc.). The second pack of the questions pertained to the secondary school studies (What type of school did they attend? What were their graduation exam results?).

The third part of test pack tried to quantify the two dependent variables: the scientific activities (scientific performance) and the attitude toward scientific career. The attitude toward scientific career was measured with 6 questions. A Likert-scale from 1 to 7 was added to every question. E.g.: "Would you like to work in academic sphere during your career?" or "Would you like to work in an international research group?" "1" meant "not at all", "7" meant "immensely willingly". The measurement of scientific activities was based on their numbers. Every question asked the quantity of the given scientific activities. E.g.: "How many times did you present on an international conference?" "How many papers of you were published in a Hungarian journal?" To more objectively quantify the scientific performance, I used a multiplier number to every activity. It was necessary, because - for example - it is much easier to create a poster to a Hungarian conference than to publish into an international journal (especially, it has impact factor). The used multiplier-point concept was adopted from the evaluation system of DETEP program (University of Debrecen) and the evaluation system of scientific scholarship at University of Pécs. Table 1 shows the used multipliers. 
Table 1. Multipliers of different scientific activities at quantifying scientific performance

\begin{tabular}{|l|l|}
\hline Article, published in a Hungarian journal or conference-book & 10 point/activity \\
\hline Article, published in an international journal or conference-book & 20 point/activity \\
\hline Chapter/sub-chapter in a scientific book & 10 point/activity \\
\hline Poster, presented in a Hungarian conference & 5 point/activity \\
\hline Poster, presented in an international conference & 10 point/activity \\
\hline Presentation in a Hungarian conference & 5 point/activity \\
\hline Presentation in an international conference & 10 point/activity \\
\hline Taking part in organization of a scientific conference & 2 point/activity \\
\hline $\begin{array}{l}\text { Taking part in a scientific conference as a visitor, merely just to learn } \\
\text { something new }\end{array}$ & 1 point/activity \\
\hline
\end{tabular}

Although, these numbers are based on real measurement systems, they are not $100 \%$ objective. Therefore, during the mathematical-statistical analysis, I investigated not only the generated index of scientific performances, but also just the numbers of scientific activities, without multiplier, but the prediction-value of the created model had been worse. Table 2 summarizes the parts of the test-packs and it shows what attributes were measured by the used questionnaires. 
Table 2. Summary of the test-pack

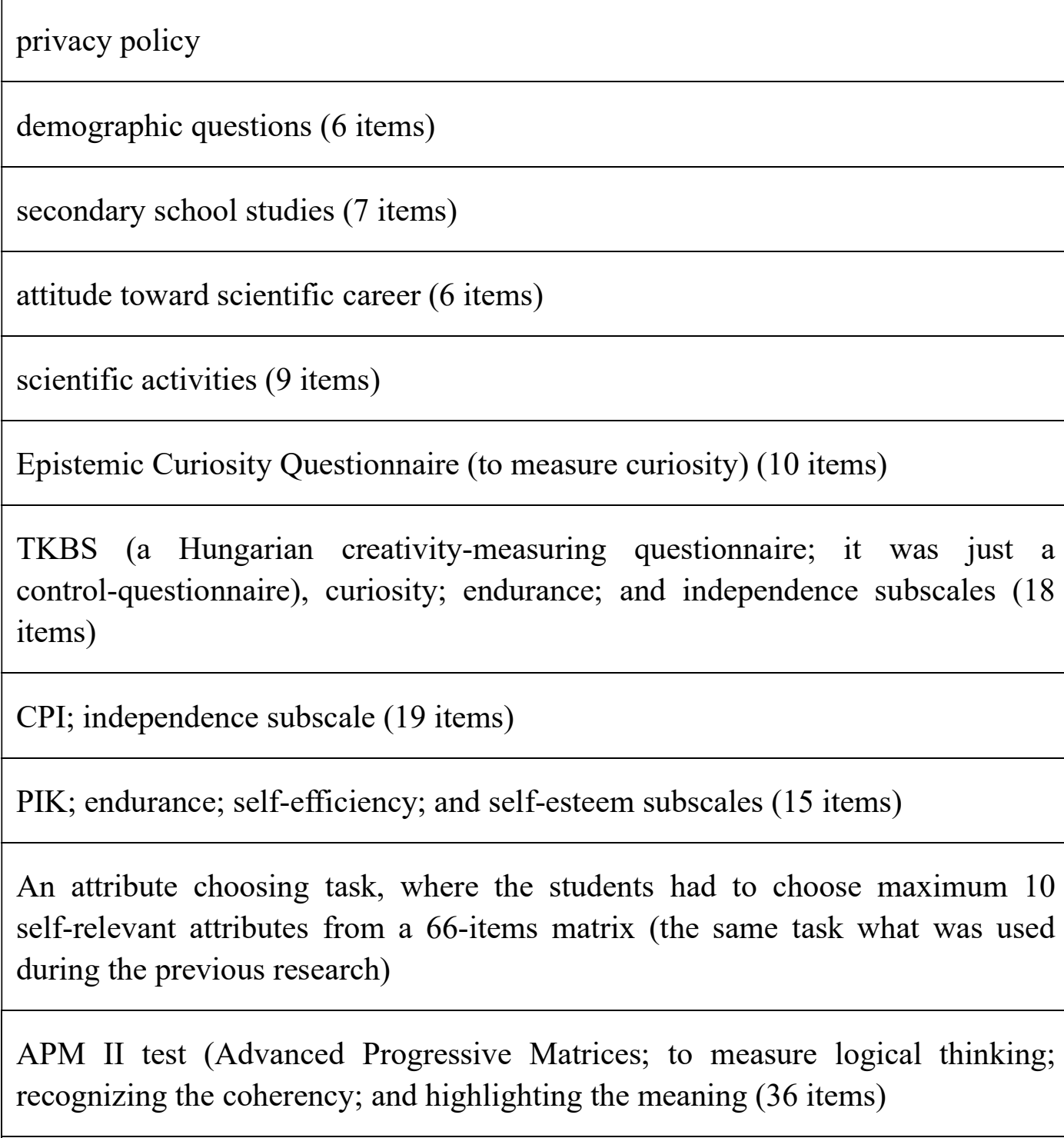

\section{Introduction of used psychological questionnaires}

Epistemic Curiosity Questionnaire (ECQ): This questionnaire contains 10 items that measures the curiosity in aspect of epistemic needs. It can be split into two subscales $(5-5$ items): diversive-, and specific epistemic curiosity. The first one refers generally to curiosity, the other refers to a given situation (Litman \& Spielberger, 2003). The measurement is based on 1-4 Likert-scales. The Hungarian adaptation was managed in 2018 with these standards: mean: 30 ; standard deviation: 4.57 .

\section{Example: Enjoy learning about subjects which are unfamiliar.}

Creativity-measuring Scale by Tóth (Tóth-féle Kreativitás Becslö Skála; TKBS): It measures the creativity with 12 subscales (Tóth \& Király, 2006). In this research, its function was control-questionnaire, because it had been developed and validated in population of primary-, and secondary school students. The TKBS contains 72 items that are based on 5-point-Likert-scale. Some items are inverse. Table 3 shows the 12 subscales with original 
standard values.

Table 3. Subscales of TKBS

\begin{tabular}{|l|l|l|}
\hline \multicolumn{1}{|c|}{ Subscale } & \multicolumn{1}{c|}{ Mean } & \multicolumn{1}{c|}{ SD } \\
\hline 1. Nonconformity & 8,6 & 4,72 \\
\hline 2. Preference of complexity & 13,08 & 5,42 \\
\hline 3. Risk-taking & 11,42 & 5,87 \\
\hline 4. Independent thinking & 12,44 & 4,84 \\
\hline 5. Intolerance & 11,71 & 5,54 \\
\hline 6. Self-actualization & 13,2 & 5,09 \\
\hline 7. Dominance & 10,82 & 5,24 \\
\hline 8. Curiosity & 14,36 & 5,5 \\
\hline 9. Dynamism & 12,82 & 5,41 \\
\hline 10. Originality & 12,31 & 4,98 \\
\hline 11. Persistence & 10,22 & 5,56 \\
\hline 12. Playfulness & 15,34 & 6,09 \\
\hline
\end{tabular}

In this research, only the Curiosity-, Persistence-, and Independent thinking subscales were used (6-6 items) because of their relevance. When the Epistemic Curiosity Questionnaire was validated in Hungarian population, the higher education standards of the used three TKBS-subscales had also been determined. Higher education standards:

Curiosity: mean: 11,02; standard deviation: 2,694;

Persistence: mean: 12,84; standard deviation: 2,644;

Independent thinking: mean: 14,67 ; standard deviation: 2,476.

Examples:

Curiosity: „I like exploring, investigating, looking after things.”

Persistence: „I learn with immense enthusiasm.”

Independent thinking: „I needn't help to manage my task.”

Psychological Immune-system Questionnaire (Pszichológiai Immunrendszer Kérdöív; PIK): It is developed for the purpose: exploring the psychological immune-system of somebody. This covers an integrated system inside the personality that provides coping-capacity for the person. This system is built up from personality traits and it can be called also coping capacity or system of protective features. The questionnaire contains 16 subscales; every subscale is measured by 5-5 items with 1-4 Likert-scales. (Oláh, 2005).

Persistence subscale: Persistence means the aggregation of the following skill that the person can continue endeavoring toward his/her goals despite of the obstacles; the frustration-toleration skill; and the skill of retention. During the Hungarian adaptation study, the following higher education standard emerged: mean: 14,48; sd: 3,255 (Oláh, 2005). 
Example: Despite of the hardness of a work or despite of problems, I continue to work, till I finish it.

California Psychological Inventory (CPI): It is a common personality-diagnostic tool (Gough, 1957). It has been validated to Hungarian to the 80 's (Oláh, 1984). There is a short -300 items containing - version of the original - 480 items containing - questionnaire that is called S-CPI. This measures the personality also with 21 subscales, with yes/no questions (Adorjáni \& Kurucz, 2014).

Independence subscale (Ai): Independence means that the person solves autonomously the problems, without external frames. This subscale contains 19 items. The standard in graduated population: among men: 11,29; among women: 10,73.

Example: "I think, in the aspect of skills and agility, I am not lower than my mates.

Raven's Progressive Matrices (RPM): I used this test to measure the logical thinking; recognizing the coherency; and highlighting the meaning. This test is an old one, but despite of this, it is used to test work-appropriateness even nowadays. The main purpose of this test is to measure inspection-skills and logical thinking. The test bases on $3 \times 3$ matrices, and the person has to choose the ninth element from 8 alternatives. The "progressive" term means that the tasks become harder during the test (Rózsa, Nagybányai-Nagy \& Oláh, 2006). Man can see an example task in Figure 1.

The test has an alternative - advanced - version developed for persons with high intelligence. It called: Raven's Advanced Progressive Matrices (APM). This advanced version is built up from 2 parts. The first part (APM-I) contains 12 items. This is a pre-test with the purpose: it helps to decide about the person whether he/she should fill out the normal test (RPM) or the advanced test (APM-II). The APM-II is the advanced version of RPM. It contains 36 tasks that are much harder than the tasks of RPM.

The APM-II was already used earlier as talent-diagnostic tool in the DETEP talent-program in University of Debrecen. During 6 years, more, than 3000 students were tested who applied for participation in the talent program. The test has been proved as a good diagnostic tool without ceiling-effect (like, at the case of RPM). Besides, it is does not discriminate between science-students and humanities-students. During this study, the Hungarian standard of this test has also been determined: mean: 23,05; sd: 4,51 (Mező \& Kurucz, 2014).

\section{Statistical analysis}

Before the mathematical-statistical analyses, it is important to check the reliability and the validity of measurement tools. I checked with Kolmogorov-Smirnov tests whether the scale-type variables fit into the normal distribution curve. The Likert-scale type measurements were investigated with Cronbach-Alpha and Kolmogorov-Smirnov tests. The results of these analyses are represented in Table 4. 
Table 4. Results of Kolmogorov-Smirnov tests and Cronbach-Alpha values

\begin{tabular}{|l|c|c|c|c|}
\hline \multicolumn{1}{|c|}{ Measurement tool } & $\begin{array}{c}\text { Kolmogorov-S } \\
\text { mirnov test }\end{array}$ & Sig. & $\begin{array}{c}\text { Cronbac } \\
\text { h Alfa }\end{array}$ & $\begin{array}{c}\text { Category of } \\
\text { Cronbach alfa }\end{array}$ \\
\hline Mean of graduation exams & $\mathrm{Z}=2,21$ & 0,000 & & \\
\hline Attitude toward scientific career & $\mathrm{Z}=1,609$ & 0,011 & 0,831 & Excellent \\
\hline Index of scientific performances & $\mathrm{Z}=2,883$ & 0,000 & & \\
\hline ECQ & $\mathrm{Z}=1,225$ & 0,099 & 0,687 & Appropriate \\
\hline TKBS-curiosity & $\mathrm{Z}=1,935$ & 0,001 & 0,721 & Good \\
\hline TKBS-independent thinking & $\mathrm{Z}=1,341$ & 0,055 & 0,617 & Appropriate \\
\hline TKBS-persistence & $\mathrm{Z}=1,282$ & 0,075 & 0,644 & Appropriate \\
\hline APM-II (RAVEN-Test) & $\mathrm{Z}=1,42$ & 0,035 & & \\
\hline PIK-persistence & $\mathrm{Z}=2,697$ & 0,000 & 0,517 & weak, but \\
appropriate \\
\hline CPI-independence & $\mathrm{Z}=1,315$ & 0,063 & & \\
\hline
\end{tabular}

The reliability values (Cronbach Alfas) are blended: they spread from weak to excellent. The normal distribution came true just in cases of ECQ, TKBS-independent thinking, TKBS-persistence, and CPI-independence, with 0.05 significance level. But if, I were use 0.1 significance level (instead of 0.05 ), there would not be a normal distribution scale.

Table 5. Correlations of used scales

\begin{tabular}{|l|l|l|}
\hline 1. test & 2. test & Correlation \\
\hline TKBS-curiosity & ECQ & Correlation: 0,26 \\
\hline TKBS-persistence & PIK-persistence & No significant Correlation \\
\hline $\begin{array}{l}\text { TKBS-independent } \\
\text { thinking }\end{array}$ & CPI-independence & No significant Correlation \\
\hline $\begin{array}{l}\text { Mean of graduation } \\
\text { exams (High school GPA) }\end{array}$ & APM-II (RAVEN-Test) & Correlation: 0,355 \\
\hline
\end{tabular}

After investigation of the reliability, I tested whether the measurements, developed for gauging the same psychological feature, correlate with each other. Table 5 shows these validation tests with correlations. It seems: just in the case of curiosity correlate the two used tests. It can be disputable to use analogy between intelligence and high-school GPA, but both of them correlates with the analytic thinking (Sternberg, 2010). That is why, I tested the correlation between APM-II and high-school GPA. It has been proved true that the two variables correlate with each other.

The first hypothesis based on the difference between the mean of talented students and the mean of the population on the scales of curiosity, independence, logical thinking, and endurance how earlier studies proved (Cognard-Black \& Spisak, 2019; Shushok, 2006; Cross, 2018).

Hypothesis 1: The participant talented students earn significantly higher means on the scales 
of TKBS, in APM II Test, in ECQ, on PIK-Endurance subscale, on CPI- self-dependence subscale, comparing with standard values (means of population).

To test hypothesis 1, I used one sample T-tests. Table 6 contains the results of T-tests.

Table 6. results of one sample T-tests

\begin{tabular}{|l|c|c|c|c|c|}
\hline \multicolumn{1}{|c|}{ Scale/subscale } & $\begin{array}{c}\text { standard } \\
\text { mean }\end{array}$ & $\begin{array}{c}\text { mean of } \\
\text { sample }\end{array}$ & T-test & df & Sig \\
\hline PIK - persistence & 14,48 & 14,04 & $\mathrm{~T}=-1767$ & $\mathrm{df}=49$ & 0,08 \\
\hline ECQ & 30 & 32,55 & $\mathrm{~T}=7,766$ & $\mathrm{df}=143$ & $0,00^{*}$ \\
\hline TKBS - curiosity & 11,02 & 11,31 & $\mathrm{~T}=1,722$ & $\mathrm{df}=143$ & 0,08 \\
\hline TKBS - persistence & 12,84 & 12,61 & $\mathrm{~T}=-0,976$ & $\mathrm{df}=143$ & 0,33 \\
\hline $\begin{array}{l}\text { TKBS -independent } \\
\text { thinking }\end{array}$ & 14,67 & 15,11 & $\mathrm{~T}=2,107$ & $\mathrm{df}=143$ & $0,03 *$ \\
\hline CPI - Independence & 11,01 & 8,03 & $\mathrm{~T}=-19,245$ & $\mathrm{df}=136$ & $0,00^{*}$ \\
\hline APM II. & 23,05 & 25,81 & $\mathrm{~T}=4,905$ & $\mathrm{df}=143$ & $0,00^{*}$ \\
\hline
\end{tabular}

The results marked with * in the column of "Sig" mean that the mean of talented students differs from the standard value in 0,05 significance level. They earned less point in the independence-subscale of CPI than the standard. There is not any difference in the aspect of persistence: the sample does not differ neither on the TKBS-subscale, not on the PIK-subscale. In the ECQ-results, the talented student earned significantly higher score than the standard, but, on the TKBS-curiosity subscale, there was not any difference. By the APM-II results, the sample performed significantly better than the standard talented higher-education results. Although, both the standard-sample and the current sample are in the "extremely high" category, according to the official Hungarian RPM evaluation-sheet.

The hypothesis came true only in three cases from seven scales: APM-II, TKBS-independent thinking and ECQ. In the case of CPI - Independence, the result has been contrary with the assumption.

The next important questions were the following: how do used questionnaires, tests and graduation exam results (as independent variables) contribute to the scientific performance and to the attitude toward the scientific career (as dependent variables)? This concept was the base of the second and third hypotheses.

Hypothesis 2: It can be created a model in which the curiosity, the endurance, the independence, the APM II test results, the attitude toward scientific career and the graduation exam results can predict the scientific performance.

To test this hypothesis, a linear regression model was used where the dependent variable was the index of scientific performance and the independent variables were: age; result of graduate-exams, PIK - persistence; ECQ; TKBS - curiosity; TKBS - persistence; TKBS -independent thinking; CPI - Independence; APM II; attitude toward scientific career. The model proved significant $(\mathrm{F}=3,453 ; \mathrm{df}=128 ; \mathrm{p}<0,05)$, but the $\mathrm{R}$-square had been 0,226 which means weak prediction-value. Significant elements in model (with $\beta$-values) are: age (0,313); 
attitude toward scientific career $(0,211)$; ECQ $(-0,198)$; CPI-independence $(-0,238)$. The last two results are unexpected and contrary with the assumption.

Hypothesis 3: It can be created a model in which the curiosity, the endurance, the independence, the APM II test results, the scientific performance and the graduation exam results can predict the attitude toward scientific career.

A second linear regression model was used to test this hypothesis where the dependent variable was the mean earned in scale of attitude toward scientific career. The independent variables were: age; result of graduate-exams, PIK - persistence; ECQ; TKBS - curiosity; TKBS - persistence; TKBS -independent thinking; CPI - Independence; APM II; the index of scientific performance. The model proved significant $(\mathrm{F}=6,79 ; \mathrm{df}=134$; $\operatorname{sig}<0,05)$, but the R-square had been also weak with 0,328. Significant elements in model (with $\beta$-values) are: ECQ $(0,303)$; TKBS-independent thinking $(0,27)$; TKBS-persistence $(-0,219)$. The last result is unexpected comparing with the assumption.

\section{Discussion}

In mathematical-statistical aspect the prediction-hypotheses (second and third hypotheses) came true, but we cannot use these results in the practice, owing to the weak prediction-value. So, statistically, can predict both the scientific performance and the attitude toward scientific career, but it worth not to bring these results into practice.

The other reason, why these scales cannot predict talent in practice: the negative $\beta$-values and the contrary results with the hypotheses. In the first regression model (about scientific performance), the ECQ and CPI-independence appeared in the model with negative $\beta$-values. This means theoretically that the more scientific activities a student performs the less curiosity and independence he has. In the second regression model (about attitude toward scientific career), the TKBS-persistence had negative B-value. Another contrary result has emerged during the first hypothesis (one sample T-tests; comparing with the standards). The talented students earned significantly lower result than the standard on CPI - Independence scale that means they are not so independent than average people. This is contrary with the literature and the results of previous step (the opinion of university-teachers) (Cognard-Black \& Spisak, 2019; Szabó, 2018).

The used scales are reliable, but we can trust in their validity, because the questionnaires, developed for measuring the same feature, correlate weakly or do not correlate with each other. The TKBS has been developed with educational purpose, but for primary and secondary school students. The ECQ, CPI, and PIK have been developed for adult people, but with personality measurement purpose, instead of educational purpose. So, it cannot be decided what scales are trustworthy.

It has been emerged during testing the first hypothesis that the talented students do not differ so much from the population in aspect of personality traits. They differed just in APM-II, TKBS-independent thinking, and ECQ. This tendency was noticeable in earlier studies that proved that talented students do not differ from their mates in every aspect, only in some cases (attributes, behavioral features, personality traits) (Cognard-Black \& Spisak, 2019; 
Shushok, 2006; Cross, 2018).

\section{Conclusion, limitations, further directions}

The contrary results (negative $ß$-values) with the hypotheses and the literature make the interpretation complicated. Although, the models could give answers for the question: which scales can predict the talent in higher education?; but the "how?" answer was not been found. So, these results indicate that the academic talent in the Hungarian higher education cannot be trustworthy measured with validated psychological questionnaires. Although, the used questionnaires have limitations: the TKBS had been developed for children and teenagers; the personality-questionnaires had been developed to measure the personality in generally, instead of in pedagogical aspect. So, a future direction can be developing a new questionnaire, with the same purpose, like the TKBS. Namely: a pedagogical talent-diagnostic questionnaire for adult people.

The one source of this "failure" (contrary results) can be found in the method (questionnaires), but the coin has also an other side: the sample. The sample is very heterogeneous, and the results do not fit to the normal distribution curve. Comparing with the American studies, which used more hundred, even more thousand participants, the number of sample $(\mathrm{N}=144)$ is small. Every second year, circle 2000-3000 students participate in the OTDK. This number is dwarfed by the number of participants in honor programs, in the USA: $300.000-400.000$ students are involved (Cognard-Black \& Spisak, 2019). The 144 participants prove that the investigation of this topic is very hard, owing to the low participation-willingness. It contributes to the heterogeneity of the sample that there are students who join to a talent program with the purpose of CV-upgrading. It is proven by a statistic number: $40 \%$ of the participants have only one or zero scientific activity. Maybe, collecting sample form an other nation, where there is complex higher education talent management, would entice more positive results. For example: in the Netherlands (Wolfensberger, 2015) or in the USA (Cross, 2018).

Age is an interesting independent variable because this has the higher beta value. This means: the older he/she is the more scientific activity he/she has. So, this can be interpreted as the following way: who will be a good scientist? - "It can be said by just the time". This result emerges a problem: the engagement problem of talents. It is not sure that a talented person is engaged his/her own talent area (Bagi, Kövi \& Mirnics, 2014). How Coyle (2009) claimed when he determined the stages of mastery: the true mastery can manifest just after the true engagement.

A potential future direction of this topic: investigating the mentoring process. In Hungary, every student, who involved into the talent-management, has at least one supervisor/mentor. The mentor is often a faculty member. It is an obligation at the TDK-applying process. It would be useful to investigate the common work of the student and his/her supervisor with a longitudinal study. The investigation of behavioral elements is also a promising option how earlier studies found (Cognard-Black \& Spisak, 2019; Shushok, 2006; Cross, 2018).

The scientific career and the research-work can be interpreted as a profession. So, this job can 
be investigated not as a talent-domain, but also a profession which requires certain competencies and expert performance (Erikson, 2006). But, in this case, it is essential to investigate this issue in science-specific aspect, instead of domain-general aspect how it was tested in this study. Even inside a science domain, there can be differences between sub-domains, for example: in geography, there are differences between social geography geology. So, another future direction could be that every institution at a university develops a special talent-identifying process, based on science-specific research-tasks.

\section{References}

Achterberg, C. (2005). What is an honors student? Journal of the National Collegiate Honors Council, 6(1), 75-83.

Adorjáni B., \& Kurucz Gy. (2014). Új norma a Rövidtett California Psychological Inventory (S-CPI) személyiségteszthez. Munkaügyi szemle, 15(5),70-83.

Allen, J. P., \& Land, D. (1999). Attachment in adolescence. In J. Cassidy, \& P. R. Shaver (Eds.), Handbook of Attachment (pp. 319-335). New York: The Guilford Press

Bagdy, E., Kövi, Zs., \& Mirnics, Zs., (2014). A tehetség kibontakozása. Helikon, Budapest, 440-453.

Balogh, L. (2012). Komplex tehetségfejlesztő programok. Didakt kiadó, Hajdúböszörmény.

Boichenko, M. (2015). Talent Management Programmes at British, American and Canadian Universities: Comparative Study. Comparative Professional Pedagogy, 5(4), 68-72. https://doi.org/10.1515/rpp-2015-0068

Bodnár, G., Takács, I., \& Balogh, Á. (2011). Tehetségmenedzsment a felsőoktatásban. Magyar Tehetségsegítő Szervezetek Szövetsége, Budapest.

Cognard-Black, A. J. \& Spisak, A. L. (2019). Creating a Profile of an Honors Student: A Comparison of Honors and Non-Honors Students at Public Research Universities in the United States. Journal of the National Collegiate Honors Council, 20(1), 123-157.

Coyle, J. (2009). The Talent Code: Greatness Isn't Born. It's Grown. Here's How. Bantam Books, New York.

Cross, T. L., Cross, J. R., Mammadov, S., Ward, T. J., Neumeister, K. S., \& Andersen, L. (2018). Psychological heterogeneity among honors college students. Journal for the Education of the Gifted, 41(3), 242-72. https://doi.org/10.1177/0162353218781754

Cuevas, A., Schreiner, L. A., Kim, Y., \& Bloom, J. (2017). Honors student thriving: A model of academic, psychological, and social wellbeing. Journal of the National Collegiate Honors Council, 18(2), 79-119.

Damon, W., Lerner, R. M., Kuhn, D., Siegler, R. S. \& Eisenberg, N. (2008). Child and adolescent development: An advanced course. Hoboken, NJ: John Wiley \& Sons.

Erikson, K. A. (2006). An Introduction to The Cambridge Handbook of Expertise and Expert 
Performance: Its Development, Organization, and Content. In Erikson, K. A., Charness, N., Feltovich, P. J. \& Hofmann, R. R. (Ed.): The Cambridge Handbook of Expertise and Expert Performance. (pp. 3-20) Cambridge University Press, New York. https://doi.org/10.1017/CBO9780511816796

Feist, G. J. (2006). The psychology of science and the origins of the scientific mind. New Haven, CT: Yale University Press.

Feist, G. J. (2011). Psychology of Science as a New Subdiscipline in Psychology. Current Directions in Psychological Science 20(5), 330-334. https://doi.org/10.1177/0963721411418471

Gandy, R., Harrison, P. \& Gold, J. (2018). Talent Management in Higher Education: Is Turnover Relevant? European Journal of Training and Development, 42(9), 597-610. https://doi.org/10.1108/EJTD-11-2017-0099

Gyarmathy, É. (2010). Hátrányban az előny. A szociokulturálisan hátrányos tehetségek. Magyar Tehetségsegítő Szervezetek Szövetsége, Budapest.

Hammer, M. H. (2015). Towards a Methodology to Identify a Talent by Using Psychological Cognitive Prototyping. Practice and Theory in Systems of Education, 10(4), 397-409. https://doi.org/10.1515/ptse-2015-0038

Hébert, T. P. \& McBee, M. T. (2007). The impact of an undergraduate honors program on gifted university students. Gifted Child Quarterly, 51(2), 136-151. https://doi.org/10.1177/0016986207299471

Helmreich, R. L., Spence, J. T., Beane, W. E., Lucker, G. W., \& Matthews, K. A.(1980). Making it in academic psychology: Demographic and personality correlates of attainment. Journal of Personality and Social Psychology, 39, 896 - 908. https://doi.org/10.1037/0022-3514.39.5.896

Hrubos I. (1999). A felsőoktatás dilemmái a tömegessé válás korszakában. Oktatáskutató Intézet, Budapest

Hua, O., Shore, B. M., Makarova, E. (2014). Inquiry-based instruction within a community of practice for gifted - ADHD college students. Gifted Education International, 30(1), 74-86. https://doi.org/10.1177/0261429412447709

Lerner, R. M. \& Lerner, L. V. (1999). Foundations and biological bases of development in adolescence. Shrewsbury, MA: Garland Publishing.

Levinson, D.J., Darrow, C.N., Klein, E.B. Levinson, M.H., \& McKee, B. (1978). Season's of a Man's Life. Knopf, New York.

Litman, J. A. \& Spielberger, C. D. (2003). Measuring Epistemic Curiosity and Its Diversive and Specific components. Journal of Personality Assessment, 80(1), 75-86. https://doi.org/10.1207/S15327752JPA8001_16

Long, E. C. J. \& Lange, S. (2002). An exploratory study: A comparison of honors \& 
non-honors students. The National Honors Report, 23(1), 20-30.

Lubinski, D., \& Humphreys, L. G. (1992). Some bodily and medical correlates of mathematical giftedness and commensurate levels of socioeconomic status. Intelligence, 16, 99-115. https://doi.org/10.1016/0160-2896(92)90027-O

Mackintosh, N. J. (1998). IQ and Human Intelligence. Oxford Univerity Press, Oxford. 103-198.

Mező F. \& Kurucz Gy. (2014). Az APM-intelligenciateszttel kapcsolatos vizsgálati tapasztalatok a Debreceni Egyetem Tehetséggondozó Programjában 2002-2008 között Géniusz mühely 4. Magyar Tehetségsegítő Szervezetek Szövetsége, Budapest

Neri, S. \& Wilkins, S. (2019). Talent Management in Transnational Higher Education: Strategies for Managing Academic Staff at International Branch Campuses. Journal of Higher Education Policy and Management, 41(1), 52-69. https://doi.org/10.1080/1360080X.2018.1522713

Oláh A. (1984). A Californiai Psychological Inventory (CPI) röviditett változatának ismertetése. Országos Pedagógiai Intézet, Budapest.

Oláh, A. (2005). Érzelmek, megküzdés és optimális élmény. Terfort Kiadó, Budapest. 85-105.

Rodgers, C. R., \& Scott, K. H. (2008). The development of the personal self and professional identity in learning to teach. In M. Cochran-Smith, S. Feiman-Nemser, D. J. McIntyre, \& K. E. Demers (Eds.), Handbook of research on teacher education: Enduring questions in changing contexts (3rd ed.). (pp. 732-755) New York: Routledge, Taylor \& Francis Group/Association of Teacher Educators.

Rózsa S., Nagybányai Nagy O. \& Oláh A. (2006). A pszichológiai mérés alapjai. Bölcsész Konzorcium, Budapest. 194-197.

Scager, K., Akkerman, S. F., Keesen, F., Mainhard, M. T., Pilot, A., \& Wubbels, T. (2012). Do honors students have more potential for excellence in their professional lives? Higher Education, 64, 19-39. https://doi.org/10.1007/s10734-011-9478-z

Shapin, S. (2009). The scientific life: A moral history of a late modern vocation. Chicago: University of Chicago Press. https://doi.org/10.7208/chicago/9780226750170.001.0001

Shushok, F. (2006). Student outcomes and honors programs: A longitudinal study of 172 honors students 2000-2004. Journal of the National Collegiate Honors Council, 7(2), 85-96.

Siegel, D. J. (1999). The developing mind (Vol. 296). New York: Guilford Press.

Simonton, D. K. (2004a). Creativity in science: Chance, logic, genius, and Zeitgeist. Cambridge University Press, Cambridge, UK. https://doi.org/10.1017/CBO9781139165358

Simonton, D. K. (2004b). Creativity as a Constrained Stochastic Process. In: Sternberg, R. J., Grigorenko, E. R., Singer, J. L. (Ed.): Creativity From Potential to Realization. (pp. 83-102) American Psychological Association. Washington, DC. 
https://doi.org/10.1017/CBO9781139165358

Sternberg, R. J. (2010). Assessment of gifted students for identification purposes: New techniques for a new millennium. Learning and Individual Differences, 20, 327-336. https://doi.org/10.1016/j.lindif.2009.08.003

Stumpf, H. (1995). Scientific Creativity: A Short Overview. Educational Psychology Review, 7(3), 225-241. https://doi.org/10.1007/BF02213372

Szabó J. (2018). A tudományos tehetség hat legfontosabb összetevője az egyetemi oktatók szempontjából. In: Koncz I. \& Szova I. (Ed.): A 15 éves PEME XVI. PhD - Konferenciájának elöadásai. (pp. 277-286) Professzorok az Európai Magyarországért Egyesület, Budapest.

Szabó J. \& Révész Gy; (2019). The most important talent-attributes in higher education talent-management - by the opinion of Hungarian talentmanagement administrators/ professionals; Advance Research Journal of Multidisciplinary Discoveries; 37(3), 17-21.

Tóth L. \& Király Z. (2006). Új módszer a kreativitás megállapítására: A Tóth-féle Kreativitás Becslő Skála (TKBS). Magyar pedagógia, 106(4), 287-311. 